\title{
Evaluation of serum proteins in relation with parasitic infections
}

\author{
Mohammad Lateef Ganaie ${ }^{* 1}$ and Khurshid Ahmad Tariq ${ }^{2}$ \\ ${ }^{1}$ Department of Animal Sciences, Central University of Kashmir, India \\ ${ }^{2}$ Department of Zoology, Islamia College of Science \& Commerce, India
}

Submission: September 24, 2018; Published: January 03, 2019

*Corresponding author: Mohammad Lateef Ganaie, Department of Animal Sciences, Central University of Kashmir, Sonwar Campus-190004, Srinagar, J\&K, India

\begin{abstract}
The present study was carried out to investigate the alteration of the blood biochemical profile in naturally infected sheep with helminth parasites. A total of 62 sheep of different age groups of both sexes were screened from registered slaughter houses for parasitic infection and consequent serum protein evaluation. The whole sampling including gut and blood samples was performed as per the standard procedures. The gut was collected in normal saline, tightened at both ends, properly labelled with age and gender and transported to the laboratory for thorough investigation for presence of parasites. The blood samples collected in neat and sterile glass vials, properly labelled and brought to the laboratory and stored at room temperature for two hours before their analysis. Lowry method was followed for quantitative determination of total protein in serum. BCG (bromocresol green) method was followed for estimation of albumin in serum. Globulin @ gm/dl was directly estimated by subtracting the estimated values of albumin to the estimated values of total protein. The findings revealed marked variation in total protein, albumin, globulin and serum pepsinogen in infected animals $(\mathrm{P}=0.02)$. The albumin levels were generally low while as globulin and serum pepsinogen were at elevated levels among the infected animals. Further, months had a significant influence on the host biochemistry with high levels of globulin in the summer season (June to August), characterized with the highest infection level.
\end{abstract}

Keywords: Albumin; Globulin; Helminth parasites; Pepsinogen; Sheep; Serum

\section{Introduction}

Parasitism is an important ecological and pathological phenomenon in animals. On several occasions parasitic infection is responsible for severe morbidity and sometimes mortality in host animals. The host physiology influences greatly the establishment of parasitic infection. The environment of a parasite is the inside of the host which provides a physical and chemical milieu, with important characteristics of $\mathrm{pH}$, oxidation reduction potential and availability of nutrients and organic/ inorganic compounds. Serum protein concentrations likely change in various clinical conditions arising due to parasitism and the decline and elevation of their level in serum indicates some disruptive activities in organ of their origin or altered membrane permeability directly or indirectly due to products and secretions of parasites. On many occasions the feeding mechanism and migratory nature of parasitic agents are responsible for these biochemical changes in the blood. Parasitic infection has been recognized as a serious health problem in sheep and causes heavy economic losses due lower production, high morbidity, mortality, besides high cost of treatment and control measures [1-3]. Out of the various parasites infecting sheep, Haemonchus contortus (stomach or barber pole worm) and Bunostomum trigonocephalum (hook worm) infections are more pronounced linked to severe blood feeding, appetite, depression, damage in gastric function, and alteration in total protein content, energy and mineral metabolism, severe anaemia, diarrhoea, loss of body weight and death [4-7]. The objective behind this study was to decipher the intensity of parasitic infection and to demonstrate the alteration in the blood biochemical profile of sheep suffering naturally with various species of parasites. Sheep being easily available for gut and blood sampling due to its heavy slaughtering in Kashmir valley due to voracious meat consumption.

\section{Material and methods}

This study forms a part of research work on parasitology carried out during our master's programme in Zoology. During this study 62 sheep of different age groups of both sexes were screened for biochemical studies.

\section{Gut collection and examination}

The gut of the sheep slaughtered in abattoirs were examined for parasitic infection through faecal examination and epg was performed by Mc Master Technique to investigate the degree and severity of infection. Briefly the gut were collected in normal saline and tightened at both ends to minimize the loss of gut contents until transported to the laboratory. The gut of the same 
slaughtered sheep were also collected, properly labelled as per age/ gender and brought to the laboratory in normal saline. It was cut open and the gut contents were minutely observed for the presence of parasites. The parasites were collected separately from abomasam, small intestine and large intestines. The parasites were preserved after thorough washing in normal saline. The parasites were temporarily mounted in glycerine jelly after proper fixation for identification.

The identification keys as provided in Souls by (1982) [8] was followed for identification of parasites and assigning them to respective taxa. The burden of the infection was expressed as mean intensity of infection. The blood samples of slaughtered sheep were collected in neat and sterile glass vials as per the standard procedures. The blood samples were brought to the laboratory and stored at room temperature for two hours before their analysis. The blood was allowed to clot, and the serum was removed after clotting. The cellular portion of the clotted blood and the serum was separated through centrifugation at $2000 \mathrm{rpm}$ for ten minutes and finally stored in refrigerator until use.

\section{Blood sample collection and examination}

The blood of the slaughtered animals was collected in properly labelled tubes filled with EDTA. The samples collected were immediately carried to the laboratory for processing. Lowry method was followed for quantitative determination of total protein in serum. Mean protein concentration was estimated as $\mathrm{mg} / \mathrm{dl}$ of the blood by the following formula Optical density of test / optical density of standard X $7.0 \mathrm{gm} / \mathrm{dl}$ BCG (bromocresol green) method was followed for estimation of Albumin in serum. The concentration of albumin was obtained by comparing the intensity of colored solution of unknown to known albumin concentration read at $630 \mathrm{~nm}$ by adopting the following formula Serum albumin = absorbance of test $/$ absorbance of standard $\mathrm{X}$ 4 gm/dl Globulin @ gm/dl was directly estimated by subtracting the estimated values of albumin to the estimated values of total protein. Finally, the whole data obtained was statistically analyzed, interpreted and tabulated.

\section{Results and Discussion}

Biochemical investigation carried out in naturally infected sheep showed marked variation in total protein, albumin, globulin and serum pepsinogen in their blood and the observations are given in the (Table 1). The different parasites observed along with their monthly prevalence and intensity of infection are also presented in the table. High levels of globulin were observed during the summer months, the period of highest infection. Variation in total protein in infected animals was statistically significant $(P=0.02)$. The mean total protein level in infected sheep was significantly lower than corresponding values in uninfected controls. Serum pepsinogen levels in infected animals were highly correlated with the level of infection and were quite high during the months of summer and post summer months and showed a decreased trend thereafter.

Table 1: Mean serological biochemical values \pm SE in naturally infected sheep with helminth parasites.

\begin{tabular}{|c|c|c|c|c|c|c|c|c|c|}
\hline Month & $\begin{array}{c}\text { Sheep } \\
\text { examined }\end{array}$ & Nematodes & Cestodes & Trematodes & $\begin{array}{l}\text { Mean Inten- } \\
\text { sity } \\
\text { of Infection }\end{array}$ & $\begin{array}{l}\text { Total pro- } \\
\text { tein } \\
\text { (5-6 gm/dl) }\end{array}$ & $\begin{array}{c}\text { Albumin } \\
(3.5-4 \\
\text { gm/dl) }\end{array}$ & $\begin{array}{l}\text { Globulin } \\
(1.5-2.5 \\
\text { gm/dl) }\end{array}$ & $\begin{array}{c}\text { Serum pep- } \\
\text { sinogen } \\
(4-5 \text { iu/l) }\end{array}$ \\
\hline June & 12 & $\begin{array}{l}\text { Trichuris ovis, } \\
\text { Haemonchus } \\
\text { contortus }\end{array}$ & $\begin{array}{l}\text { Moniezia } \\
\text { expansa }\end{array}$ & $\begin{array}{l}\text { Paraphistomum } \\
\text { Fasciola hepatica }\end{array}$ & $\begin{array}{c}\mathrm{N}++++ \\
\mathrm{C}++ \\
\mathrm{T}+\end{array}$ & $6.8 \pm .1$ & $2.8 \pm .61$ & $3.3 \pm .6$ & $5.97 \pm 1.96$ \\
\hline July & 18 & $\begin{array}{l}\text { Trichuris ovis, } \\
\text { Haemonchus } \\
\text { contortus }\end{array}$ & $\begin{array}{c}\text { Moniezia } \\
\text { expansa } \\
\text { Avitellina }\end{array}$ & Paraphistomum & $\begin{array}{c}\mathrm{N}++++ \\
\mathrm{C}++ \\
\mathrm{T}+\end{array}$ & $5.86 \pm .18$ & $2.9 \pm 0.59$ & $2.9 \pm .4$ & $5.5 \pm 1.89$ \\
\hline Aug & 10 & $\begin{array}{l}\text { Haemonchus } \\
\text { contortus } \\
\text { Trichuris ovis }\end{array}$ & $\begin{array}{l}\text { Moniezia } \\
\text { expansa } \\
\text { Avitellina }\end{array}$ & Fasciola hepatica & $\begin{array}{l}\mathrm{N}++ \\
\mathrm{C}+ \\
\mathrm{T}+\end{array}$ & $6.05 \pm .12$ & $3.3 \pm 0.5$ & $2.6 \pm .4$ & $4.4 \pm .94$ \\
\hline Sep & 10 & Trichuris ovis & $\begin{array}{c}\text { Moniezia } \\
\text { expansa } \\
\text { Avitellina }\end{array}$ & - & $\begin{array}{l}\mathrm{N}+ \\
\mathrm{C}+ \\
\mathrm{T}+\end{array}$ & $5.11 \pm .09$ & $2.7 \pm 0.4$ & $2.3 \pm .3$ & $4.4 \pm .92$ \\
\hline Oct & 12 & Trichuris ovis & $\begin{array}{l}\text { Moniezia } \\
\text { expansa }\end{array}$ & - & $\begin{array}{c}\mathrm{N}+++ \\
\mathrm{C}+\end{array}$ & $5.2 \pm .08$ & $3.4 \pm 0.65$ & $1.8 \pm .2$ & $4.6 \pm .96$ \\
\hline
\end{tabular}

Significant increase in the level of globulin and serum pepsinogen in naturally infected and $\mathrm{H}$. contortus experimentally infected sheep over control in the present study, were similar to the observations made by several authors in various parts of the world. The fall in total serum proteins in the infected animals compared to control was similar to observations of [9] who reported a significant fall in total serum protein and albumin in ruminants infected with nematodes. The initial sudden fall in the present study might be due to haemo-dilation, a compensatory mechanism of abomasal hemorrhages caused by invading larvae, and later on due to the loss of large quantities of serum proteins into the gut and the consequent increased fractional catabolic rate of albumin [10].

The serum pepsinogen concentrations were significantly elevated by infection. This hyper secretion of serum pepsinogen might be due to decline of chief cell granule content seen in some infected animals. Prolonged, strong stimulation of pepsinogen production and secretion could result in the direct release of pepsinogen without granule formation [11]. The mechanism/s responsible for an increase in blood pepsinogen levels are very complicated and may be multifactorial in origin involving 
direct stimulation of zymogenic cells by factors released from the parasite, indirect stimulation via elevated circulating concentration of hormone such as gastrin and leakage from abomasal fluid between poorly differentiated epithelial cells [12]. However, Scott [13] reported no significant difference in overall pepsinogen content between control and infected animals and concluded that this masked the conflicting effects of a reduced pepsinogen content of chief cells and an increase in total number of pepsinogens producing cells. Increase in the level of globulin in the serum could be due to the humoral immune response manifested by the animals against nematode infections [14]. Significant increase in total protein concentration may arise from an increase in total globulins usually of the gamma globulin [15]. A decrease in total protein concentration is usually the result of a fall in albumin or sometimes gamma globulins. The findings of the present study will be quite useful to understand the biochemical pathology of sheep infected with nematodes.

\section{References}

1. Iqbal Z, Akhtar M, Khan MN, Riaz M (1993) Prevalence and economic significance of Haemonchosis in sheep and goats slaughtered at Faisalabad abattoir. Pak J Agri Sci 30(1): 51-53.

2. Tariq KA, Chishti MZ, Ahmad F, Shawl AS (2006) Epidemiological studies on Haemonchosis of Sheep in Kashmir Valley. Orient Sci 12: 43-47.

3. Qamar MF, Maqbool A (2012) Biochemical studies and serodiagnosis of haemonchosis in sheep and goats. The Jr of Anim \& Plant Sci 22(1): 32-38.

4. Dhar DN, Sharma RL, Bansal GC (1982) Gastrointestinal nematodes in sheep in Kashmir. Vet Parasitol 11(2-3): 271-277.

5. Sharma DK, Chauhan PPS, Agarwal, RD (2001) Changes in the levels of serum enzymes and total protein during experimental Haemonchosis in Barbari goats. Small Ruminant Research 42 (2): 119-123.
6. Vatta AF, Letty BA, van der Linde MJ, van Wijk EF, Hansen JW, et al. (2001) Testing for clinical anaemia caused by Haemonchus spp. in goats farmed under resource-poor conditions in South Africa using an eye color chart developed for sheep. Vet Parasitol 99(1): 1-14.

7. Agarwal MC, Banerjee PS (2007) Problems confronting helminthic diseases of domestic animals in India. J Parasit Dis 31: 3-13.

8. Soulsby EJL (1982) Helminths, Arthropods and Protozoa of Domesticated Animals, $7^{\text {th }}$ ed. The English Language Book Society and Bailliere Tindall, London. pp. 234.

9. Pralomkarn W, Pandey VS, Ngampongsai S (1997) Gastrointestinal Helminthic and Protozoal Infections of Goats in Satun, Thailand. Vet Parasitol 68: 79-90.

10. Dargie JD, Allonby EW (1975) Pathophysiology of single and challenge infection of Haemonchus contortus infection in Merino sheep: studies on red cell kinetics and the "self-cure" phenomenon. Int J Parasitol 5(2): 147-157.

11. Hersey SJ (1987) Pepsinogen secretion. In physiology of gastrointestinal tract, $2^{\text {nd }}$ (ed) (Johnson, L R), Raven, Press, New York, pp. 947.

12. McKellar QA (1993) Interactions of Ostertagia spp. with their bovine and ovine hosts. Int J Parasitol 23(4): 451-462.

13. Scott I, McKellar Q (1995) The effects of excretory/secretory products of Ostertagia circumcincta on pepsinogen secretion and smooth muscle contraction in abomasal tissue derived from previously infected sheep and in parasite-naïve animals. Proceedings of the $15^{\text {th }}$ International Conference of the World Association of Veterinary Parasitology. $2^{\text {nd }}$, Japan, pp. 138 .

14. Ahmad A, Anwarul Hassan, Anwarul Haq, Majeed MA (1990) serum protein changes of lambs in experimentally induced with Haemonchus contortus infection. Veterineriski-Arhir 60(4): 195-200.

15. Bhat TK (1983) Biochemical changes in blood of lambs experimentally infected with Oesophagostomum Columbianum. Ind J Parasitol 7: 130.

\section{Your next submission with Juniper Publishers will reach you the below assets}

- Quality Editorial service

- Swift Peer Review

- Reprints availability

- E-prints Service

- Manuscript Podcast for convenient understanding

- Global attainment for your research

- Manuscript accessibility in different formats

( Pdf, E-pub, Full Text, Audio)

- Unceasing customer service

Track the below URL for one-step submission

https://juniperpublishers.com/online-submission.php 